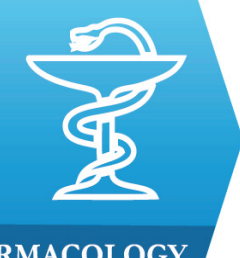

PHARMACOLOGY
1) Doctoral Programme of Biomedical Science Student, Faculty of Medicine, Universitas Sriwijaya, Palembang, Indonesia

2) Department of Pharmacology, Faculty of Medicine, Universitas Sriwijaya, Palembang, Indonesia

3) Department of Biology, Faculty of Medicine, Universitas Sriwijaya, Palembang, Indonesia

4) Department of Psychiatry, Faculty of Medicine, Universitas Sriwijaya, Palembang, Indonesia

\title{
Evaluation of the anti-gout effect of Sonchus Arvensis on monosodium urate crystal-induced gout arthritis via anti-inflammatory action - an in vivo study
}

Nita Parisa ${ }^{1,2}$, Rachmat Hidayat ${ }^{3}$, Ziske Maritska $^{3}$, Bintang Arroyantri Prananjaya ${ }^{4}$

\begin{abstract}
Background and aims. Sonchus arvensis is an Indonesian plant with strong therapeutic effects. Various studies have shown that this plant is useful in treating kidney stone disorders, and recent studies have shown that $S$. arvensis extract can reduce inflammation caused by monosodium urate crystal deposition in the synovial tissue. This study was aimed to explore the extract of Sonchus arvensis, via fractionation, to optimize the specific content of $S$. arvensis with anti-inflammatory potential in gout arthritis.

Methods. The study included 30 rats (Rattus norvegicus) Wistar strain obtained from the Eureka Research Laboratory (Palembang, Indonesia) weighing between 200 - 250 grams. After one week of acclimatization, the rats were randomly divided into six groups, each group containing five animals; normal control group, monosodium urate group (negative control), colchicine group, hexane fraction of $S$. arvensis group, ethylacetate fraction of $S$. arvensis group and water fraction group. Before monosodium urate administration, rats in the colchicine group, as a positive control group, were given orally for seven days with $0.28 \mathrm{mg} / \mathrm{kg} / \mathrm{day}$ colchicine. IL-1 $\beta$ levels in joint synovial fluid were examined with Rat ELISA interleukin-1 $\beta$.

Results. S. arvensis water fraction showed the most significant reduction in inflammatory cells compared to the hexane or ethyl acetate fractions. The water fraction of $S$. arvensis group had an equal effect with positive control in reducing the infiltration of inflammatory cells in the synovial tissue.

Conclusion. Sonchus arvensis water fraction has anti-gout effects in monosodium urate-induced gout arthritis in rats by decreasing the inflammatory response in the synovial joint.
\end{abstract}

Keywords: Gouty arthritis, anti-inflammatory agents, plant extracts, kidney calculi

\section{Background and aims}

Gouty arthritis is a chronic inflammatory condition characterized by severe pain and severe swelling of one or more synovial joints. This disorder is caused by excessive nucleic acid metabolism and leads to the deposition of monosodium urate (MSU) crystals in the synovial space [1]. Deposition of MSU crystals in the joint synovial tissue will cause an inflammatory reaction at the deposition site in the form of leukocyte infiltration and is followed by phagocytosis by macrophages/monocytes. This condition is followed by membrane lysis, the production of reactive oxygen species (ROS) and the release of lysozyme enzymes [2].

Reactive oxygen species will cause oxidative stress in cells and joint tissues; wherein there will be stimulation of the inflammatory pathway cascade 
due to the activation of the transcription factor, nuclear factor-kB (NF-KB). Activation of NF-KB will lead to the activation of transcription and translation of the protein cytokine interleukin 1B (IL-1B) and activation of tumor necrotic factor $\alpha(\mathrm{TNF}-\alpha)$ cytokines [3]. Activation of these pro-inflammatory cytokines will lead to erosion and damage to joint tissues. Nonsteroidal anti-inflammatory drugs (naproxen and indomethacin), corticosteroids and colchicine are the first-line therapy for gouty arthritis and myelosuppression [4-5]. Therefore, it is desirable to explore new therapeutic modalities that are superior in dealing with inflammation due to gouty arthritis and minimal side effects.

Indonesia is a country with the second-largest biological wealth in the world after Brazil. With such enormous natural potential, it is very reasonable that this grace of nature should be explored optimally to obtain new therapeutic modalities for gout arthritis. Sonchus arvensis is widely distributed throughout the Indonesia, and a member of Asteraceae family. This plant is usually consumed as raw food (salad) in Indonesia as a cheap and common source of proteins, vitamins and minerals. Consumption of this plant, especially as fresh food (raw), is believed to be effective in overcoming various health problem such as hepatotoxicity [6], nephrotoxicity [7], cardiotoxicity [8,9], asthma [10], brain dysfunction [11], adrenal dysfunction [12], and oxidative stress [13].

S. arvensis has a strong anti-inflammatory potential [14] with the presence of flavonoid compounds (luteolin, luteolin 7-O glucoside, kaempferol, orientin, quercetin) $[15,16]$. S. arvensis flavonoid content is an essential secondary metabolite that plays a role in suppressing the inflammatory process due to crystal deposition-monosodium urate in joint tissue through suppression of ROS activity on monosodium urate-deposited tissue [17-20]. This study was aimed to explore the extract of Sonchus arvensis, by $S$. arvensis fractionation, to optimize the specific content of Sonchus arvensis with anti-inflammatory potential in gout arthritis.

\section{Methods}

\section{Animal model}

The study was carried out on 30 rats (Rattus norvegicus) Wistar strain obtained from the Eureka Research Laboratory (Palembang, Indonesia) weighing between $200-250$ grams. All rats were kept in cages under controlled conditions of 12 hour day and night cycle, temperature $22 \pm 1^{\circ} \mathrm{C}$ and room moistness $40-60 \%$ and given food ad libitum. The research treatments and procedures received approval from the medical research ethics committee of the Faculty of Medicine, Universitas Sriwijaya (No. 187 / kptfkunsri-rsmh / 2020).

\section{Tempuyung fractionation preparation}

Simplicia of Sonchus arvensis were obtained from the Tawangmangu Herbal Research Center, Karanganyar,
Indonesia, by first carrying out the determination test of plant species at the Biological Research Center of the Indonesian Institute of Sciences (LIPI) (No.780/ IPH.1.02/ If.8/V/2020). S. arvensis extraction process was carried out by maceration in which 500 grams of simplicia were macerated with $96 \%$ ethanol for 72 hours. Furthermore, the separation process of dregs and macerate were done. Macerate continued with the fractionation process with n-hexane, ethyl acetate and water solvents, to obtain the $\mathrm{n}$-hexane fraction $(\mathrm{FH})$, ethyl acetate fraction (FE) and water fraction (FA) from $S$. arvensis.

\section{MSU crystal synthesis}

A total of 0.8 grams of uric acid was liquefied in $155 \mathrm{~mL}$ of aqua bidest containing $5 \mathrm{~mL}$ of $\mathrm{NaOH}(1 \mathrm{M})$, $\mathrm{pH}$ 7.2. The gouty blend was frozen and stirred at room temperature and stored overnight at $4^{\circ} \mathrm{C}$. Next, the residue was purified from the solution, dried at $70^{\circ} \mathrm{C}$ for 4 hours, prepared into a fine powder, sieved with a 200 mesh metal filter, sterilized at $180^{\circ} \mathrm{C}$ temperature for two hours and saved in sterile conditions. Before administration, MSU crystals were suspended in saline-buffered phosphate, $\mathrm{pH}$ 7.2 at $20 \mathrm{mg} / \mathrm{mL}$.

\section{Animal model of gout arthritis}

After one week of acclimatization, the rats were randomly divided into the following six groups, each containing five rats: normal control group (Con), monosodium urate (MU) group (negative control); monosodium urateinduced and colchicine $(0.28 \mathrm{mg} / \mathrm{kg})$ treatment group (Pos); monosodium urate-induced and n-hexane fraction of $S$. arvensis $(20 \mathrm{mg} / \mathrm{kg})$ treatment $(\mathrm{FH})$ group; monosodium urate-induced and ethyl acetate fraction of $S$. arvensis $(20$ $\mathrm{mg} / \mathrm{kg}$ ) treatment (FE) group; and monosodium urateinduced and water fraction of $S$. arvensis $(20 \mathrm{mg} / \mathrm{kg})$ treatment (FA) group. Before MU administration, rats in the Pos group, as a positive control group, were given orally for seven days with $0.28 \mathrm{mg} / \mathrm{kg} /$ day colchicine (Dexa Medica, Indonesia). The animals in the treatment group were given n-hexane fraction (FH), ethyl acetate fraction (FE) and water fraction (FA) of $S$. arvensis once daily for a week, and the dosage used was $20 \mathrm{mg} / \mathrm{kg}$ each rat. The control group and the model group were given the same amount of $0.9 \%$ saline $(10 \mathrm{ml} / \mathrm{kg})$ used a sonde for a week. Furthermore, arthritis gout was induced on the seventh day, an hour after treatment. The rats were anesthetized by injecting $10 \%$ chloral hydrate $(3.5 \mathrm{~mL} / \mathrm{kg})$ intraperitoneally. Before that, each rat in the treatment group was given $50 \mathrm{ml}$ of monosodium-urate solution $(20 \mathrm{mg} / \mathrm{ml})$ and injected into the left ankle joint gap. Each rat in the control group received an injection of $50 \mu \mathrm{l}$ of saline in the cavity of the left ankle joint. Rats were sacrificed with an intraperitoneal injection of $10 \%$ chloral hydrate. Evacuation of the joint synovial fluid, which was then performed centrifugal rotation at $10,000 \mathrm{rpm}$ for ten minutes and temperature $25^{\circ} \mathrm{C}$. The supernatant was kept at $-20^{\circ} \mathrm{C}$ for analysis of IL- $1 \beta$ examination using the ELISA method. 
Meanwhile, the joint synovial tissue was evacuated, some of which were homogenized and centrifuged to obtain a supernatant and put it in a later RNA solution (Sigma Aldrich, Singapore) and stored at $-20^{\circ} \mathrm{C}$, for western blotting TNF- $\alpha$ examination. Part of the synovial tissue was fixed in $4 \%$ paraformaldehyde buffer for histopathological evaluation of the synovial tissue.

\section{Histopathological evaluation}

Synovial tissue that was fixed with $4 \%$ paraformaldehyde buffer was dehydrated using graded alcohol and xylene, then paraffined and cut to a $5 \mathrm{um}$ thickness using a spinning microtome (Leica, Weitzar, Germany). The result of the cuts was then placed on a glass object and dyed with hematoxylin and eosin. Histopathological changes in synovial tissue were interpreted under a microscope (Olympus, Tokyo, Japan).

\section{IL-1及}

Enzyme-linked immunosorbent assays (ELISA)

IL-1 $\beta$ levels in the joint synovial fluid were examined with Rat ELISA IL-1 $\beta$ (Cloud Clone, Hangzhou, China), based on the manufacturer's protocols. In brief, $50 \mu \mathrm{l}$ of standard diluent or serum samples were added to the well coated with anti-IL- $1 \beta$ and incubated at $37^{\circ} \mathrm{C}$ for 30 minutes. After the plates were washed, $100 \mu 1$ of the biotinylated antibody compound was added and set for 30 minutes at $37^{\circ} \mathrm{C}$. After rinsing three times, $50 \mathrm{ul}$ avidinperoxidase complex solution was added and incubated for 15 minutes at $37^{\circ} \mathrm{C}$. After that, $50 \mu \mathrm{l}$ of tetramethylbenzidine colour solution was added and set in the darkness for 15 minutes at $37^{\circ} \mathrm{C}$. Subsequently, $50 \mathrm{ul}$ stop solution was added to stop the reaction, and the optical density (OD) was assessed using an ELISA reader (Biorad, California, USA), the wavelength of $450 \mathrm{~nm}$.

\section{Western blot TNF- $\alpha$}

This process begins with the protein extraction stage. The synovial tissue of the joints was put into a RIPA buffer (Sigma Aldrich, Hangzhou, China) equipped with PMSF on frozen water for 5 minutes. After centrifugation process at $12.000 \mathrm{rpm}$ for ten minutes at $4^{\circ} \mathrm{C}$, the supernatant was collected as total protein lysate. Cytoplasmic and nuclear proteins were extracted from the synovial tissue using a protein extraction kit (Sigma Aldrich, Hangzhou, China), according to the manufacturer's protocol. In short, the synovial tissue is cut into small pieces and homogenized with a protein extraction agent. After incubation on ice for fifteen minutes and centrifugation at $5000 \mathrm{rpm}$ for 5 minutes at $4^{\circ} \mathrm{C}$, the supernatant was accumulated as partial cytoplasmic protein, while the pellets were re-extracted in the extraction buffer. After keeping on ice for 15 minutes and centrifugation process at $12.000 \mathrm{rpm}$ for 5 minutes at $4^{\circ} \mathrm{C}$, the supernatant was combined with cytoplasmic proteins. The pellets were then again extracted in the extraction buffer and shook hard for thirty minutes at $4^{\circ} \mathrm{C}$. After centrifugation at $12.000 \mathrm{rpm}$ for ten minutes at $4^{\circ} \mathrm{C}$, the protein was collected. The total protein concentration was quantified using the BCA Protein Assay (Sigma Aldrich, Hangzhou, China) kit.

A total of $40 \mu \mathrm{g}$ of extract protein was separated at SDS-PAGE $10 \%$. Next, the isolated protein was transferred to the PVDF (Millipore) membrane and blocked with 5\% non-fat milk on Triss-buffered saline with Tween 20 for an hour at room temperature. The membranes were incubated overnight at $4^{\circ} \mathrm{C}$ with rabbit polyclonal TNF- $\alpha$ 1:700 primary antibodies (Cloud Clone, Hangzhou, China). Moreover, incubation was carried out with secondary antibodies, horseradish peroxidase-conjugated goat anti-rabbit 1: 5000 for 45 minutes at $37^{\circ} \mathrm{C}$. Furthermore, the results of blotting were visualized with chemiluminescence (Biorad, California, USA). Blotting was standardized by blotting $\beta$-actin.

\section{Phytochemical test}

Test for phenols

The test was performed by using the method of Sofowora [21]. $2 \mathrm{ml}$ extract was taken in a beaker glass. Then, $2 \mathrm{ml}$ of ferric chloride solution was added. A deep bluish-green solution indicated the presence of phenols.

\section{Test for terpenoids}

Salkowski test was performed by using the method of Edeoga et al [22]. $5 \mathrm{ml}$ of aqueous extract was mixed in $2 \mathrm{ml}$ of chloroform. Then $3 \mathrm{ml}$ of concentrated sulfuric acid was poured to form a layer. A reddish-brown coloration of interface indicated the presence of terpenoids.

\section{Test for saponins}

The test was performed using the method of Edeoga et al [22]. $2 \mathrm{~g}$ of the powdered sample boiled in $20 \mathrm{ml}$ of distilled water in a water bath and filtered the solution. Then $10 \mathrm{ml}$ of the filtrate was mixed with $5 \mathrm{ml}$ of distilled water and shaken vigorously for a stable, persistent foam. The foam was mixed with three drops of olive oil and shake vigorously, which leads to the formation of the emulsion; indicated the presence of saponins.

\section{Test for flavonoids}

The test was performed by using the method of Harborne [23]. $1 \mathrm{~g}$ powdered sample was heated with 10 $\mathrm{ml}$ ethyl acetate over a steam bath $\left(40-50^{\circ} \mathrm{C}\right)$ for 5 minutes. The filtrate was treated with $1 \mathrm{ml}$ dilute ammonia. A yellow coloration demonstrated positive test for flavonoids.

B-actin Test for alkaloids

The test was performed by using the method of Harborne [23]. $1 \mathrm{~g}$ powdered sample was extracted with $5 \mathrm{ml}$ methanol and $5 \mathrm{ml}$ of $2 \mathrm{~N}$ hydrochloric acid. Then the filtrate was tested with Meyer's and Wagner's reagents. The samples were scored positive, based on turbidity.

\section{Statistical analysis}

All data were presented as mean \pm standard deviation, and statistical analysis was performed with the SPSS 25 (IBM) program. One way ANOVA accompanied by a post hoc analysis was carried out to assess the difference in mean expression levels of each protein. $\mathrm{P}<0.05$ was determined as an indication that there was a significant difference in mean levels. 


\section{Results}

Tissue evaluation and analysis with H\&E staining were performed on each $S$. arvensis fraction. Figure 1 , shows that when compared with the control group, the histopathological features of the MU model group showed a large number of inflammatory cells showing the reaction of inflammation. Besides, the inflammation response decreased in the $S$. arvensis fraction treatment group. $S$. arvensis water fraction showed the most significant reduction in inflammatory cells compared to the hexane or ethyl acetate fractions. The water fraction of $S$. arvensis group had an equal effect with positive control in reducing the infiltration of inflammatory cells in the synovial tissue.
Table I. Level of IL-1 $\beta$ in synovial fluid.

\begin{tabular}{c|c|c|c} 
No. & Group & IL-1 $\boldsymbol{\beta}(\mathbf{p g} / \mathbf{m L}) \pm$ SD & p-value* \\
\hline 1. & Con & $28.26 \pm 3.41$ & 0.001 \\
2. & MU & $496.23 \pm 15.43$ & - \\
3. & Pos & $97.41 \pm 7.21$ & 0.001 \\
4. & FH & $386.12 \pm 21.43$ & 0.001 \\
5. & FE & $298.11 \pm 18.65$ & 0.001 \\
6. & FA & $155.83 \pm 10.12$ & 0.001
\end{tabular}

Notes: Con: normal control group, MU: monosodium urateinduced group (negative control), Pos: monosodium urateinduced and colchicine treatment group (positive control), FH: monosodium urate-induced and hexane fraction of $S$. arvensis group, FE: monosodium urate-induced and ethyl acetate fraction of $S$. arvensis group, FA: monosodium urate-induced and water fraction of $S$. arvensis group.

* vs MU; ANOVA, pos hoc Bonferroni; $\mathrm{p}<0,05$

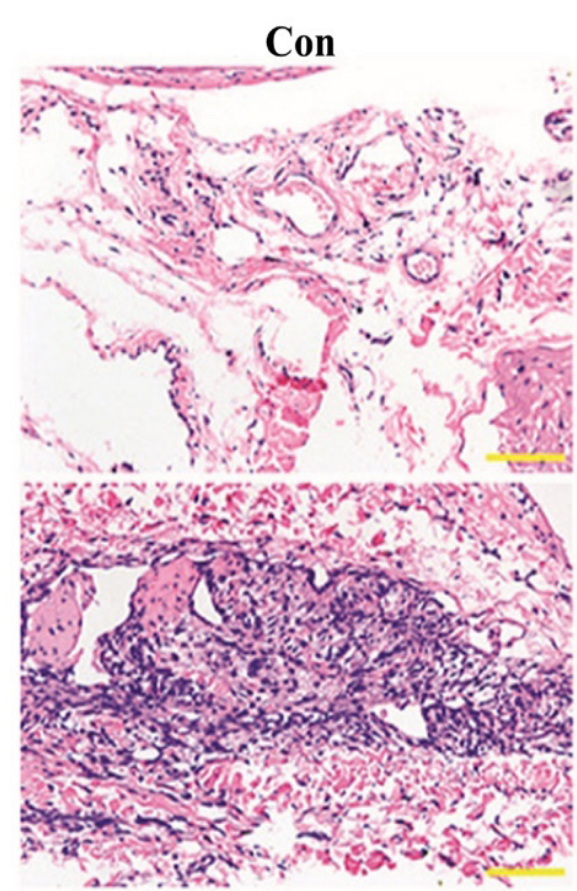

FH

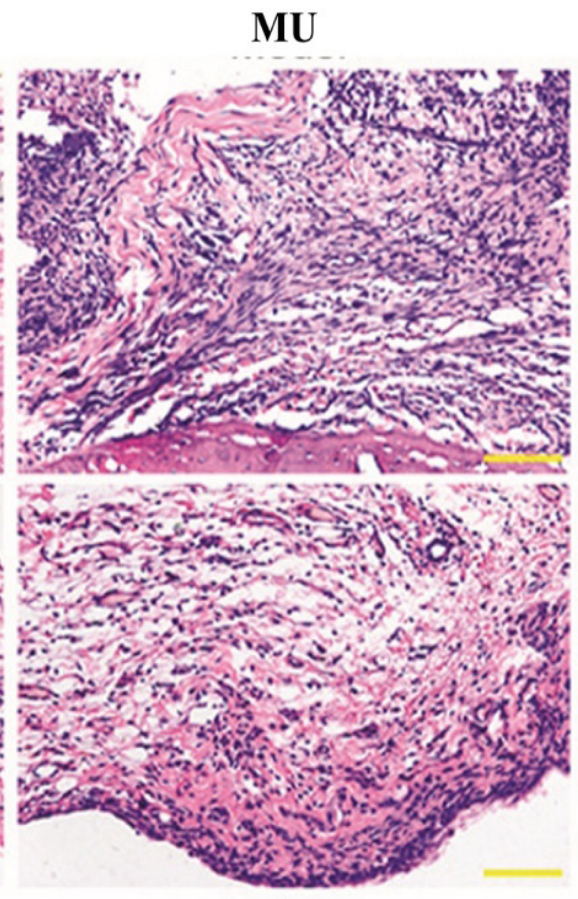

FE

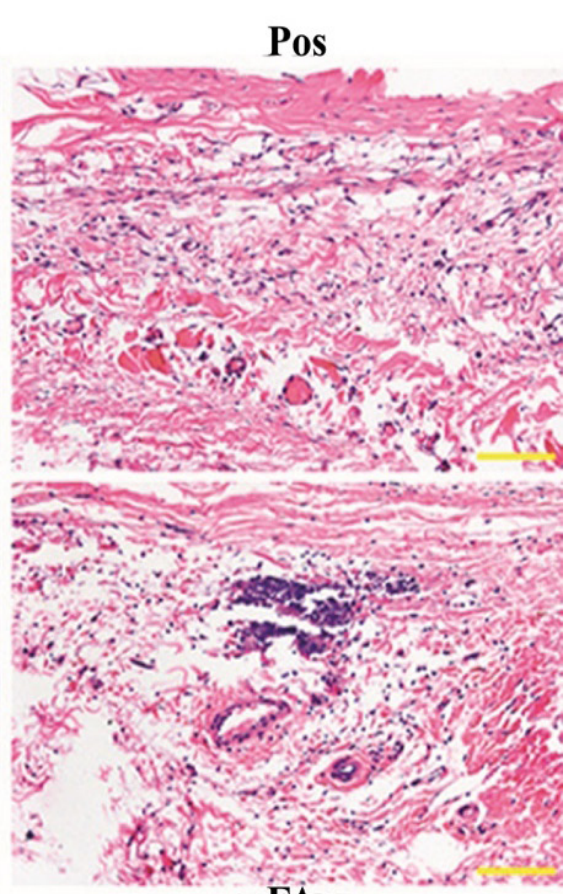

$\mathbf{F A}^{-}$

Figure 1. Effect of fraction $S$. arvensis on monosodium urate-induced gout arthritis and inflammatory cell infiltration. Hematoxylin and eosin stained for histological assessment. Con: normal control group, MU: monosodium urate- induced group (negative control), Pos: monosodium urate- induced and colchicine treatment group (positive control), FH: monosodium urate-induced and hexane fraction of $S$. arvensis group, FE: monosodium urate-induced and ethyl acetate fraction of $S$. arvensis group, FA: monosodium urate-induced and water fraction of S. arvensis group. Magnification x 200 .

Table II. Phytochemical test of $S$. arvensis fraction.

\begin{tabular}{l|c|c|c|c|c}
\hline S. arvensis fraction & Saponin & Alkaloid & Triterpenoid & Phenol & Flavonoid \\
\hline n-hexane fraction & + & - & ++ & ++ & - \\
Ethyl acetate fraction & + & + & - & + & + \\
Water fraction & + & + & + & + & ++
\end{tabular}




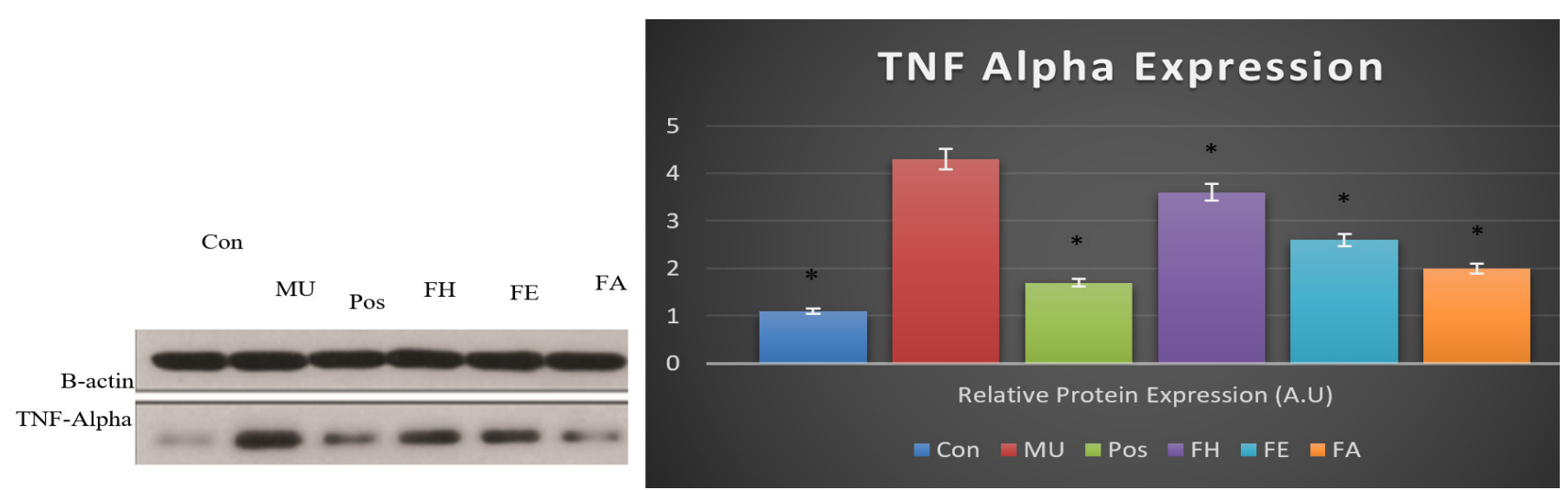

Figure 2. Effect of S.arvensis fraction on monosodium urate-induced TNF alpha activation in synovial of rats. Con: normal control group, MU: monosodium urate- induced group (negative control), Pos: monosodium urate- induced and colchicine treatment group (positive control), FH: monosodium urate-induced and hexane fraction of $S$. arvensis group, FE: monosodium urate-induced and ethyl acetate fraction of $S$. arvensis group, FA: monosodium urate-induced and water fraction of $S$. arvensis group.

* $\mathrm{p}<0,05$ versus model group; ANOVA, pos-hoc Bonferroni.

Table I shows in the experimental group of animals that were induced with monosodium urate increased levels of IL-1B in the synovial tissue. This result indicates that monosodium urate induction causes inflammation of the synovial tissue. The administration of $S$. arvensis fraction showed the ability to reduce IL-1B levels where the largest decrease was seen in the group that received the $S$. arvensis water fraction treatment.

Figure 2 shows the potential of the $S$. arvensis fraction in reducing the expression of the pro-inflammatory cytokine protein, TNF alpha. Water fraction of $S$. arvensis was able to reduce the expression of TNF alpha protein more potently than the hexane and ethyl acetate fractions.

Table II shows that each fraction shows a difference in the content of active metabolites contained. The hexane fraction is rich in triterpenoids and phenol, while the water fraction is rich in flavonoids.

\section{Discussion}

Quality of life improvement results in the increase of the incidence of gouty arthritis. Gouty arthritis is an inflammatory disease caused by the accumulation of monosodium urate fragments in the joints. The underlying mechanism is the activation of the inflammatory cascade induced by monosodium urate fragments, which has been investigated for several years, and several studies have shown that pro-inflammatory cytokines, as well as IL- $1 \beta$ and TNF- $\alpha$, and transcription factor, NF- $\kappa B$, are essential. In the initiation and propagation of gouty arthritis induced by monosodium urate fragments [24-29]. In the pathophysiology of gouty arthritis, NF- $\mathrm{kB}$ signaling can encourage the production of genes encoding proinflammatory cytokines.
In contrast, overexpression of TNF- $\alpha$ and IL- $1 \beta$ can directly stimulate the NF- $\mathrm{KB}$ pathway, lead to a positive feedback loop, then amplify the inflammatory response and cause joint damage [30-34]. Usually, NF-kB attaches to the inhibiting protein, I $\mathrm{K} \mathrm{B}$, and is localized in the cytoplasm. Particular stimuli, including monosodium urate fragments, can cause a reduction of I $\mathrm{KB}$ and translocation of NF$\kappa \mathrm{B}$ into the nucleus where it controls the transcription of different target genes [35-39]. In this study, serum IL-1 $\beta$ and TNF- $\alpha$ levels were considerably increased in response to monosodium urate fragments.

Exploration of natural ingredients as a new modality in the management of gout arthritis is a necessity, given the absence of optimal control of this disorder [40,41]. $S$. arvensis is a medicinal plant with optimal potency for the management of gout arthritis $[42,43]$. This study showed that $S$. arvensis was able to reduce the inflammatory response caused by the induction of uric acid crystals in the joints. This study indicates that $S$. arvensis extract can reduce the expression of pro-inflammatory cytokines, IL- $1 \beta$ and TNF- $\alpha$. It is well known that the accumulation and intrusion of neutrophils into the joint and synovial fluid are the main features of gouty arthritis [44-49]. After monocytes and neutrophils were activated, these cells actively phagocytose monosodium urate fragments, which further triggers an inflammatory caspase response [50-54]. Therefore, prevention of inflammatory cell infiltration may be a potent therapeutic strategy against gouty arthritis [50]. The histopathological results in this research showed that the water fraction of $S$. arvensis significantly attenuated the infiltration of inflammatory cells into the synovium caused by monosodium urate fragments and increased synovial hyperplasia. The water fraction is rich in secondary 
metabolites, flavonoids, where they are compounds that act as antioxidants. The antioxidant ability of flavonoids is known to be an inhibitor of oxidant activity (reactive oxygen species) [46]. Suppression of reactive oxygen species activity will decrease the action of the inflammatory cascade in the synovial tissue.

Luteolin and apigenin, a class of flavonoids contained in $S$. arvensis, significantly inhibited TNF $\alpha$-induced NF- $\mathrm{BB}$ transcriptional activation. However, they did not affect the degradation of $\mathrm{I} \kappa \mathrm{B}$ proteins and the nuclear translocation and DNA binding activity of NF- $\mathrm{KB}$ p65. Interestingly, the suppression of NF- $\mathrm{KB}$ activation by these flavonoids is due to inhibition of the transcriptional activation of NF- $\mathrm{KB}$, since the compounds markedly inhibited the transcriptional activity of GAL4-NF- $\mathrm{kB}$ p65 fusion protein [54-55].

Quercetin, one of the class flavonoids in S. arvensis, inhibits the proliferative phase of inflammation and probably may act by inhibition. This impact may be due to the cellular migration to injured sites and accumulation of collagen. Cell migration appears as a result of a much different process, including adhesion and cell mobility. Flavonoids are naturally occurring compounds contained in S. arvensis. Such compounds have been noticed to have anti-inflammatory features, both in vitro and in vivo [56]. Several flavonoids have been found out to have significant anti-inflammatory activity [57]. This study has emphasized that the flavonoids are in charge of its anti-inflammatory action.

\section{Conclusion}

Sonchus arvensis water fraction has an anti-gout effect in monosodium urate-induced arthritis in rats by decreasing the inflammatory response in the synovial joint.

\section{References}

1. Chagas VC, Franca LM, Malik S, Paes AMA. Syzigium cumini (L.) skeels: a prominent source of bioactive molecules against cardiometabolic diseases. Front Pharmacol. 2015; 6: 259.

2. Sumarya IM, Adiputra N, Sukrama IDM, Putra-Manuaba IB. Betel leaf extract (Piper betle L.) antihyperuricemia effect decreases oxidative stress by reducing the level of MDA and increase blood SOD levels of hyperuricemia wistar rats (Rattus norvegicus). Bali Med J. 2016;5:263-267.

3. Widyaningsih TD, Putri WD, Murtini ES, Rochmawati $\mathrm{N}$, Nangin D. Anti-inflammatory and anti-hyperuricemia properties of chicken feet cartilage : treatment on gouty arthritis animal model. J Appl Pharm Sci. 2017;7:202-207.

4. Wang W, Bhole VM, Krishnan E. Chronic kidney disease as a risk factor for incident gout among men and women: retrospective cohort study using data from the Framingham Heart Study. BMJ Open. 2015;5:e06843.

5. Yang M, Teng G, Li G, Huang T, Xu R. Effectiveness of osthole on uric acid crystal-induced acute gouty arthritis through the inhibition of NLRP3 inflammasome. I
International Journal of Pharmacology. 2018;14:1169-1178.

6. Khan RA, Khan MR, Sahreen S, Shah NA. Hepatoprotective activity of Sonchus asper against carbon tetrachlorideinduced injuries in male rats: a randomized controlled trial. BMC Complement Altern Med. 2012;12:90.

7. Shehzadi I, Shah NA, Khan MR, Shuaib M, Shah M, Khan A, et al. In vivo antioxidant potential of Raphanus sativus seeds in rat kidney against CCl-4 induced toxicity. Pol J Environ Study. 2020; 29: 277-284.

8. Khan MR, Badar I, Siddiquah A. Prevention of hepatorenal toxicity with Sonchus asper in gentamicin treated rats. BMC Complement Altern Med. 2011; 11: 113.

9. Hamed MA, Ali SA, El-Rigal NS. Therapeutic potential of ginger against renal injury induced by carbon tetracchloride in rats. The Scientific World Journal. 2012; 2012: 840421.

10. Khan RA, Khan MR, Sahreen S. Protective effect of Sonchus asper extracts against experimentally induced lung injuries in rats: a novel study. Exp Toxicol Pathol. 2012;64:725-731.

11. Khan RA, Khan MR, Sahreen S. Brain antioxidant markers, cognitive performance and acetylcholinesterase activity of rats: efficiency of Sonchus asper. Behav Brain Funct. 2012;8:21.

12. Khan MA, Khan MR, Sahreen S, Bokhari J. Prevention of CCl4-induced nephrotoxicity with Sonchus asper in rat. Food Chem Toxicol. 2010; 48: 2469-2476.

13. Khan RA, Khan MR, Sahreen S, Ahmed M. Evaluation of phenolic contents and antioxidant activity of various solvent extracts of Sonchus asper (L.) Hill. Chem Cent J. 2012;6:12.

14. Vilela FC, Bitencourt AD, Cabral LD, Franqui LS, Soncini R, Giusti-Paiva A. Anti-inflammatory and antipyretic effects of Sonchus oleraceus in rats. J Ethnopharmacol. 2010;127:737741.

15. Bramwell D, Dakshini KMM. Luteolin 7-glucoside and hydroxycoumarins in Canary Island Sonchus species. Phytochemistry. 1971;10:2245-2246.

16. Khan RA. Evaluation of flavonoids and diverse antioxidant activities of Sonchus arvensis. Chem Cent J. 2012;6:126.

17. Huang Q, Duan Z, Yang J, Ma X, Zhan R, Xu H, et al. SNP typing for germplasm identification of Amomum villosum Lour. Based on DNA barcoding markers. PLoS One. 2014;9:e114940.

18. Jiang Y, You XY, Fu KL, Yin WL. Effects of extract from Mangifera indica leaf on monosodium urate crystal-induced gouty arthritis in rats. Evid Based Complement Alternat Med. 2012;2012:967573.

19. Lee H, Choi HS, Park Y, Ahn CW, Jung SU, Park SH, et al. Effects of deer bone extract on the expression of proinflammatory cytokine and cartilage-related genes in monosodium iodoacetate-induced osteoarthritic rats. Biosci Biotechnol Biochem. 2014;78:1703-1709.

20. Lee YM, Shon EJ, Kim OS, Kim DS. Effects of Mollugo pentaphylla extract on monosodium urate crystal-induced gouty arthritis in mice. BMC Complement Altern Med. 2017; 17:447.

21. Sofowora A. Screening plants for bioactive agents. In: Medicinal plants and traditional medicinal in Africa. $2^{\text {nd }}$ ed. Ibadan: Nigeria; 1993: p. 134-156. 
22. Edeoga HO, Okwu DE, Mbaebie BO. Phytochemical constituents of some Nigerian medicinal plants. Afr J Biotechnol. 2005;4:685-8.

23. Harborne JB. Phytochemical methods - A guide to modern techniques of plant analysis. $2^{\text {nd }}$ ed. New Delhi: Springer Pvt Ltd; 2005: p. 99-105.

24. Hidayat R, Reagan M, Hayati L. Tempuyung (Sonchus arvensis) ameliorates monosodium urate crystal-induced gouty arthritis in rats through anti-inflammatory effects. Open Access Maced J Med Sci; 2020:8(A): 220-224.

25. Nugraheni PW, Rahmawati F, Mahdi C, Prasetyawan S. Green tea extract (Camellia sinensis L.) effects on uric acid levels on hyperuricemia rats (Rattus norvegicus). J Pure Appl Chem Res. 2017;6;246-254.

26. Park JE, Yeom Z, Park KT, Han EH, Yu HJ, Kang HS, et al. Hypouricemic effect of ethanol extract of Aster glehni leaves in potassium oxonate-induced hyperuricemic rats. Clin Nutr Res. 2018;7;126-135.

27. Abu Bakar FI, Abu Bakar MF, Rahmat A, Abdullah N, Sabran SF, Endrini S. Anti-gout potential of Malaysian medicinal plants. Front Pharmacol. 2018;9:261.

28. Hsu DZ, Chen SJ, Chu PY, Liu MY. Therapeutic effects of sesame oil on monosodium urate crystal-induced acute inflammatory response in rats. Springerplus. 2013;2;659.

29. Silva CR, Fröhlich JK, Oliveira SM, Cabreira TN, Rossato MF, Trevisan G, et al. The antinociceptive and antiinflammatory effects of the crude extract of Jatropha isabellei in a rat gout model. J Ethnopharmacol. 2013;145:205-213.

30. Hussein YM, Mohamed RH, Pasha HF, El-Shahawy EE, Alzahrani SS. Association of tumor necrosis factor alpha and its receptor polymorphisms with rheumatoid arthritis in female patients. Cell Immunol. 2011; 271: 192-196.

31. Moilanen LJ, Hämäläinen M, Lehtimäki L, Nieminen RM, Moilanen E. Urate crystal induced inflammation and joint pain are reduced in transient receptor potential ankyrin 1 deficient mice--potential role for transient receptor potential ankyrin 1 in gout. PLoS One. 2015;10:e0117770.

32. Li L, Teng M, Liu Y, Qu Y, Zhang Y, Lin F, et al. Antigouty arthritis and antihyperuricemia effects of sunflower (Helianthus annuus) head extract in gouty and hyperuricemia animal models. Biomed Res Int. 2017;2017:5852076.

33. Kou Y, Li YF, Xu M, Li WY, Yang M, Li RL. Effects of RuPeng15 powder (RPP15) on monosodium urate crystalinduced gouty arthritis in rats. Evid Based Complement Alternat Med. 2015;2015:527019.

34. Han J, Xie Y, Sui F, Liu C, Du X, Liu C, et al. Zisheng Shenqi decoction ameliorates monosodium urate crystal-induced gouty arthritis in rats through anti-inflammatory and antioxidative effects. Mol Med Rep. 2016;14:2589-2597.

35. Xia Z, Qu W, Lu H, Fu J, Ren Y, Liang J. Sesquiterpene lactones from Sonchus arvensis L. and their antibacterial activity against Streptococcus mutans ATCC 25175. Fitoterapia. 2010;81:424-428.

36. Sabitha V, Ramachandran S, Naveen KR, Panneerselvam K. Antidiabetic and antihyperlipidemic potential of Abelmoschus esculentus (L.) Moench in streptozotocininduced diabetic rats. J Pharm Bioallied Sci. 2011; 3: 397-
402.

37. Radulović N, Blagojević P, Palić R. Fatty acid derived compounds-the dominant volatile class of the essential oil poor Sonchus arvensis subsp. uliginosus (Bieb.) Nyman. Nat Prod Commun. 2009;4:405-410.

38. Rock KL, Kataoka H, Lai JJ. Uric acid as a danger signal in gout and its comorbidities. Nat Rev Rheumatol. 2013;9:13-23.

39. Huang J, Wang S, Zhu M, Chen J, Zhu X. Effects of genistein, apigenin, quercetin, rutin and astilbin on serum uric acid levels and xanthine oxidase activities in normal and hyperuricemic mice. Food Chem Toxicol. 2011;49:19431947.

40. Perez-Ruiz F, Lioté F. Lowering serum uric acid levels: what is the optimal target for improving clinical outcomes in gout? Arthritis Rheum. 2007;57:1324-1328.

41. Lin KC, Lin HY, Chou P. The interaction between uric acid level and other risk factors on the development of gout among asymptomatic hyperuricemic men in a prospective study. J Rheumatol. 2000;27:1501-1505.

42. Fels E, Sundy JS. Refractory gout: what is it and what to do about it? Curr Opin Rheumatol. 2008;20:198-202.

43. Li H, Zhao M, Su G, Lin L, Wang Y. Effect of soy sauce on serum uric acid levels in hyperuricemic rats and identification of flazin as a potent xanthine oxidase inhibitor. J Agric Food Chem. 2016;64:4725-4734.

44. Murugaiyah V, Chan KL. Mechanisms of antihyperuricemic effect of Phyllanthus niruri and its lignan constituents. J Ethnopharmacol. 2009;124:233-239.

45. Wang WL, Sheu SY, Huang WD, Chuang YL, Tseng HC, Hwang TS, et al. Phytochemicals from Tradescantia albiflora kunth extracts reduce serum uric acid levels in oxonateinduced rats. Pharmacogn Mag. 2016;12(Suppl 2):S223S227.

46. Wang M, Zhao J, Zhang N, Chen J. Astilbin improves potassium oxonate-induced hyperuricemia and kidney injury through regulating oxidative stress and inflammation response in mice. Biomed Pharmacother. 2016;83:975-988.

47. Lee HM, Yang G, Ahn TG, Kim MD, Nugroho A, Park HJ, et al. Antiadipogenic effects of Aster glehni extract: in vivo and in vitro effects. Evid Based Complement Alternat Med. 2013;2013:859624.

48. Samatha T, Shyamsundarachary R, Srinivas P, Swamy NR. Quantification of total phenolic and total flavonoid contents in extracts of Oroxylum indicum L. Kurz. Asian J Pharm Clin Res. 2012;5:177-179.

49. Al-Farsi M, Al-Amri A, Al-Hadhrami A, Al-Belushi S. Color, flavonoids, phenolics and antioxidants of Omani honey. Heliyon. 2018; 4: e00874.

50. Liu LM, Cheng SF, Shieh PC, Lee JC, Chen JJ, Ho CT, et al. The methanol extract of Euonymus laxiflorus, Rubia lanceolata and Gardenia jasminoides inhibits xanthine oxidase and reduce serum uric acid level in rats. Food Chem Toxicol. 2014;70:179-184.

51. Azmi SM, Jamal P, Amid A. Xanthine oxidase inhibitory activity from potential Malaysian medicinal plant as remedies for gout. Int Food Res J. 2012;19:159-165. 
52. Liu K, Wang W, Guo BH, Gao H, Liu Y, Liu XH, et al. Chemical evidence for potent xanthine oxidase inhibitory activity of ethyl acetate extract of Citrus aurantium L. dried immature fruits. Molecules. 2016;21:302.

53. Jang IT, Hyun SH, Shin JW, Lee YH, Ji JH, Lee JS. Characterization of an anti-gout xanthine oxidase inhibitor from Pleurotus ostreatus. Mycobiology. 2014;42:296-300.

54. Gao JJ, Hu YW, Wang YC, Sha YH, Ma X, Li SF, et al. ApoM supresses TNF- $\alpha$-induced expression of ICAM-1 and VCAM-1 through inhibiting the activity of NF-kB. DNA Cell Biol. 2015; 34: 550-556.
55. Oh J, Kim JH, Park JG, Yi YS, Park KW, Rho HS, et al. Radical scavenging activity-based and AP-1-targeted antiinflammatory effects of lutein in macrophage-like and skin keratinocytic cells. Mediators Inflamm. 2013;2013:787042.

56. Robinson AM, Miller S, Payne N, Boyd R, Sakkal S, Nurgali K. Neuroprotective potential of mesenchymal stem cellbased therapy in acute stages of TNBS-induced colitis in guinea pigs. PLOS One. 2015; 10: e0139023.

57. Kim HP, Son KH, Chang HW, Kang SS. Effects of naturally occurring flavonoid on inflammatory response and their action mechanism. Natural Product Sciences. 2000;6:170178. 